\title{
Cytotoxic, colony formation and anti-migratory effects of Spilanthes acmella (Asteraceae) aerial extract on MCF-7 cells and its cream formulation
}

\author{
Supavadee Boontha ${ }^{1 *}$, Thatcha Thoedyotin ${ }^{1}$, Thanaphon Saengtabtim ${ }^{1}$, Pathitta \\ Im-erb' ${ }^{1}$, Natthamon Chaniad ${ }^{1}$, Benjaporn Buranrat ${ }^{2}$, Tasana Pitaksuteepong ${ }^{3}$ \\ ${ }^{1}$ School of Pharmaceutical Sciences, University of Phayao, Phayao 56000, ${ }^{2}$ Faculty of Medicine, Mahasarakham University, \\ Maha Sarakham 44000, ${ }^{3}$ Department of Pharmaceutical Technology, Faculty of Pharmaceutical Sciences, Naresuan \\ University, Phitsanulok 65000, Thailand
}

${ }^{\star}$ For correspondence: Email: supa0865@hotmail.com; Tel: +66-54-466666

Sent for review: 27 September 2019

Revised accepted: 18 December 2019

\begin{abstract}
Purpose: To determine anti-breast cancer activities of Spilanthes acmella (S. acmella) extract. Methods: S. acmella was macerated with $95 \%$ ethanol. Phenolic, flavonoid content and antioxidant activity of the extract were assessed using Folin Ciocalteu method, aluminum chloride (AICl3) colorimetric method and 2, 2-diphenyl-1-picrylhydrazyl (DPPH) radical scavenging assay, respectively. Cytotoxicity, colony formation and cell migration suppression on MCF-7 cells, representing anti-breast cancer effects, were also evaluated by sulforhodamine $B(S R B)$, clonogenic and wound healing assays, respectively. Creams containing the extract were formulated and then characterized in terms of their physical appearance, viscosity and $\mathrm{pH}$, before and after stability testing.

Results: The crude extract contained phenolic content of $62.8 \pm 5.2 \mathrm{mg}$ gallic acid equivalent/g and flavonoid content of $375.6 \pm 20.1 \mathrm{mg}$ rutin equivalent/g. The results showed that the extract exhibits antioxidant effect with half-maximal inhibitory concentration $\left(I C_{50}\right)$ of $1.2 \pm 0.1 \mathrm{mg} / \mathrm{mL}$. It showed cytotoxicity on MCF-7 cells with $I C_{50}$ of $37.1 \pm 1.1 \mu \mathrm{g} / \mathrm{mL}$ in $48 \mathrm{~h}$ and inhibited colony formation of cells with $I C_{50}$ of $44.9 \pm 1.3 \mu \mathrm{M}$. In addition, it demonstrated an anti-migration effect at a concentration of 50 $\mu \mathrm{g} / \mathrm{mL}$. The developed creams displayed good physical appearance and maintained stable physical properties overt a two-month period.

Conclusion: S. acmella extract exhibits potential anti-breast cancer activity. The cream containing the extract is promising for the topical treatment of breast cancer.
\end{abstract}

Keywords: Spilanthes acmella, Antioxidant, Anti-breast cancer, Flavonoids, Phenolics, Topical cream

This is an Open Access article that uses a fund-ing model which does not charge readers or their institutions for access and distributed under the terms of the Creative Commons Attribution License (http://creativecommons.org/licenses/by/4.0) and the Budapest Open Access Initiative (http://www.budapestopenaccessinitiative.org/read), which permit unrestricted use, distribution, and reproduction in any medium, provided the original work is properly credited.

Tropical Journal of Pharmaceutical Research is indexed by Science Citation Index (SciSearch), Scopus, International Pharmaceutical Abstract, Chemical Abstracts, Embase, Index Copernicus, EBSCO, African Index Medicus, JournalSeek, Journal Citation Reports/Science Edition, Directory of Open Access Journals (DOAJ), African Journal Online, Bioline International, Open-J-Gate and Pharmacy Abstracts

\section{INTRODUCTION}

Cancer is the second-leading cause of death for humans worldwide after cardiovascular diseases [1]. The estimated number of deaths caused by cancer worldwide will be more than 13.1 million by the year 2030 [2,3]. Among various cancers, breast cancer is considered the most serious health problem worldwide for women. Treatment with drugs and surgery is currently the standard used for breast cancer. However, the failure of breast cancer treatment is generally reported due 
to drug resistance and drug toxicity [4,5]. Therefore, a more effective and safer anti-breast cancer agent is needed. Medicinal plants have gained intensive focus for being effective and value-added sources of anticancer agents [6].

Spilanthes acmella (S. Acmella) belongs to the Asteraceae family. This edible medicinal plant is a well-known treatment for toothaches because of its anesthetic effect $[7,8]$. In addition, it is used for the treatment of fever, pain, flu, gastric ulcer and malaria in traditional medicine around the world $[9,10]$. However, there is no data for the anticancer activity of the extract of $S$. acmella. Among the various bioactive compounds found in medicinal plants, flavonoids and phenolic generally respond to antioxidant activity. In addition, it has been reported that plants enriched with antioxidant activity exhibit in vitro anticancer activity [11]. This is due to cancer being closely linked to oxidative stress in the human body after exposure to free radicals. Thereafter, gene mutations may occur, resulting in carcinogenesis. For the anti-breast cancer activity of plant extract, cytotoxic effect on breast cancer cells is required. Also, the inhibition of replicative ability and the suppression of metastasis in the cells require necessary investigation. This is due to metastasis and the proliferation of cancer cells after treatment with either surgery or chemotherapy related to the potential of recurrence for breast cancer [12]. Generally, colony formation assay is used to determine the replicative ability of cancer cells, while wound healing assay is used to determine the migration of cancer cells $[13,14]$. Therefore, the inhibition of colony formation and the suppression of cell migration effects of the extract on human MCF-7 breast cancer cells were evaluated in this study.

Topical formulations are convenient and minimize side effects when compared to other administration routes. Nowadays, there are topical formulations of 5-fluorouracil (5-FU), diclofenac and imiquimod for skin cancer treatment [15]. Additionally, patients with cutaneous metastasis breast cancer have been treated with chemotherapy combined with topical treatment, either 5-FU cream or imiquimod cream, in order to produce effective outcomes and better quality of life [16,17]. Creams are interesting as a topical formulation in this study because one or more active compounds can be dispersed or dissolved in the formulation [18]. Compared to ointments, creams are more preferable for many patients because of the ease of spreading and removal after application onto the skin. Thus, the current study aimed to determine the phytochemical screening, phenolics, flavonoids, antioxidant activity and anti-breast cancer activities of $S$. acmella extract. Creams containing the extract was further formulated.

\section{EXPERIMENTAL}

\section{Preparation of plant sample and S. acmella extract}

The plant sample (voucher no. 110896) was identified and deposited at the Queen Sirikit Botanic Garden (QBG) Herbarium, Chiang Mai. The aerial part of the plant was cleaned with water, chopped into small pieces and air-dried. It was then dried at $50{ }^{\circ} \mathrm{C}$ using a hot-air oven for $48 \mathrm{~h}$. The dried plant was ground into powder and was macerated with $95 \%$ ethanol for $72 \mathrm{~h}$. Following filtration, the extract was concentrated using a rotary evaporator (Heidolph, Germany) at a controlled temperature of $50{ }^{\circ} \mathrm{C}$. The yield of the extract was determined using $\mathrm{Eq} 1$.

Yield $(\%)=\{($ DWCE $)(D W P)\} 100$

where DWCE is the dry weight of the crude extract and DWLP is the dry weight of the $S$. acmella plant powder.

\section{Phytochemical screening}

Phytochemical screening of the extract was evaluated by specific chemical reaction for secondary metabolites including flavonoids, alkaloids, tannins, cyanogenic glycosides, saponins, antraquinones, terpenes and steroids [19]. The intensity of color or the formation of precipitate was used as positive responses to the screening tests.

\section{Determination of phenolic and flavonoid contents}

\section{Phenolic content}

In order to determine the phenolic content of the extract, $80 \mu \mathrm{L}$ of Folin-Ciocalteu reagent was added to $40 \mu \mathrm{L}$ of the extract solution (200 $\mu \mathrm{g} / \mathrm{mL}$ ), which was then mixed together. After incubation for $5 \mathrm{~min}, 80 \mu \mathrm{L}$ of $7 \%$ sodium carbonate $\left(\mathrm{Na}_{2} \mathrm{CO}_{3}\right)$ was added to the mixture. Thereafter, the reaction mixture was incubated for $30 \mathrm{~min}$. The absorbance was measured at $750 \mathrm{~nm}$ using a microplate reader (Synergy H1, Biotek Instruments, Friedrichshall, Germany). The phenolic content was calculated from the standard curve of gallic acid $(20-100 \mu \mathrm{g} / \mathrm{mL})$ and presented as gallic acid equivalent (GAE) per gram of crude extract. 


\section{Flavonoid content}

In order to determine the flavonoid content of the extract, $100 \mu \mathrm{L}$ of $2 \% \mathrm{AlCl}_{3}$ solution was added to $100 \mu \mathrm{L}$ of the extract solution $(100 \mu \mathrm{g} / \mathrm{mL})$. After incubation for $10 \mathrm{~min}$, the absorbance was measured at $415 \mathrm{~nm}$. The flavonoid content was calculated from the standard curve of rutin (20 $100 \mu \mathrm{g} / \mathrm{mL}$ ) and presented as rutin equivalent (RE) per gram of crude extract.

\section{DPPH radical scavenging activity}

Briefly, $100 \mu \mathrm{L}$ of each extract solution (0.05 - 2.0 $\mathrm{mg} / \mathrm{mL}$ ) was mixed separately with $100 \mu \mathrm{L}$ of 5.0 $\mathrm{mM}$ DPPH in a 96-well plate. After incubation for $20 \mathrm{~min}$, the absorbances of the blank (without the test sample, $\left.A b_{\text {blank }}\right)$ and the sample $\left(A b_{\text {sample }}\right)$ were determined at $540 \mathrm{~nm}$. Gallic acid was served as a positive control. DPPH radical scavenging ability (S) was calculated using Eq 2.

$\left.S(\%)=\left(\left(A b_{\text {blank }}-A b_{\text {sample }}\right)\right) / A b_{\text {blank }}\right) \times 100$

Evaluation of the effects of $S$. acmella extract on cytotoxicity, colony formation and cell migration

\section{Cytotoxicity assay}

The MCF-7 breast cancer cell (ATCC \#HTB-22; Manassas, VA, USA) was cultured in Dulbecco's modified Eagle's medium (DMEM) supplemented with $10 \%$ fetal bovine serum (FBS), streptomycin $(100 \mu \mathrm{g} / \mathrm{mL})$ and penicillin (100 $\mathrm{U} / \mathrm{mL}$ ). The cytotoxic effect of the extract was assessed by the Sulforhodamine B (SRB) method, as previously described $[20,21]$. The cells were plated and then treated with the medium containing $S$. acmella extract in a dose of $0-500 \mu \mathrm{g} / \mathrm{mL}$ for $48 \mathrm{~h}$. Then, they were stained with $0.4 \%$ SRB dye solution at room temperature. After incubation for $30 \mathrm{~min}$, the free SRB dye was discarded from the cells by washing several times, then solubilized in $10 \mathrm{mM}$ Tris base buffer $(\mathrm{pH}$ 7.4). Absorbance was measured at $540 \mathrm{~nm}$.

Table 1: Composition of cream base

\section{Clonogenic assay}

In the determination of the colony formation inhibition of the extract, viable cells (500 cells) were plated in a 6-well plate and incubated for 24 h. Then, the $S$. acmella extract $(100 \mu \mathrm{L})$ with various concentrations were added and further incubated for $24 \mathrm{~h}$. The cells were then washed, and the fresh culture medium was added. After that, the cells were cultured for another 10 days (the cell culture medium was changed every 2 days). Thereafter, $0.5 \%$ crystal violet in methanol was used to stain the cultured cells, and the colony number was determined by direct counting method.

\section{Cell migration assay}

The cells were plated in a 24-well culture plate for $24 \mathrm{~h}$ at $37^{\circ} \mathrm{C}$. Then, a straight wound in each well was created by scratching the cell using a sterile pipette tip. The extract solution $(0-100$ $\mu \mathrm{g} / \mathrm{mL}, 100 \mu \mathrm{L}$ ) was added and incubated for 48 $h$. Thereafter, the area of the uncovered region of the wound was measured using an inverted microscope (TS100, Nikon, Japan) at a magnification of $\times 10$. The percentage of relative closure of the scratch, indicating the antimigratory effect of the extract, was calculated from the area data.

\section{Preparation, characterization and stability study of cream bases}

Cream bases were formulated using the cold process. The ingredients of the cream bases are shown in Table 1. The oil phase consisted of light mineral oil and Novemer ${ }^{T M}$ EC-1, while the water phase consisted of polysorbate 20, Supguard GM-BP and purified water. The ingredients of the oil and water phases were dissolved separately and then mixed together with constant stirring using a stirring rod. In this investigation, the total weight of the oil phase was varied in the range of 3-8 \%w/w, named cream bases 1, 2 and 3 .

\begin{tabular}{llccc}
\hline \multirow{2}{*}{ Composition } & \multirow{2}{*}{ Function } & \multicolumn{3}{c}{ Amount (g) } \\
\cline { 2 - 4 } & & Cream base-1 & Cream base-2 & Cream base-3 \\
\hline Light mineral oil & Oil phase & 2 & 3 & 4 \\
Novemer ${ }^{M}$ EC-1 & Rheology modifier & 1 & 3 & 4 \\
Polysorbate 20 & Emulsifier & 0.5 & 0.5 & 0.5 \\
Supguard GM-BP & Preservative & 0.5 & 0.5 & 0.5 \\
Purified water & Water phase & 91 & 93 & 96 \\
Total weight & - & 100 & 100 & 100 \\
\hline
\end{tabular}

Note: Novemer "MI EC-1 Polymer = Acrylates/Acrylamide copolymer 26 - 28\%, mineral oil (NF Grade) 22 - 24\%, polysorbate 851 - 3\% and water 45 - 51\%; Supguard GM -BP = Diazolidinyl urea, iodopropynyl butylcarbamate and propylene glycol 


\section{Characterization of cream bases}

The characteristics of the prepared cream bases were studied as follows:

\section{Physical appearance}

The physical appearances of the cream bases in terms of color, smoothness and homogeneity were observed.

\section{Viscosity determination}

The viscosity of cream bases was measured at $25{ }^{\circ} \mathrm{C}$ using a Brookfield DV-II programmable rheometer equipped with a CP52 cone and plate spindle (Brookfield Engineering laboratories Inc., Massachusetts, USA).

\section{pH determination}

The $\mathrm{pH}$ of cream bases was measured at $25^{\circ} \mathrm{C}$ using a pH meter (SevenEasy, Mettler Toledo, USA).

\section{Stability study}

The stability of the cream bases was performed using a heat/cool cycling test. In a cycling test, the cream bases were kept in sealed containers. The samples were kept at $4{ }^{\circ} \mathrm{C}$ for $24 \mathrm{~h}$, followed by $60{ }^{\circ} \mathrm{C}$ for $24 \mathrm{~h}$. This process was carried out for six cycles. Thereafter, the physical appearance, viscosity and $\mathrm{pH}$ of the cream bases were evaluated, as mentioned above.

\section{Preparation, characterization and stability study of creams containing the extract}

After evaluation of the physical properties and stability test, the cream base with suitable viscosity and $\mathrm{pH}$ for topical use was selected and subjected to incorporation of the extract. The extract was added into the selected creams by dissolving the extract in water phase. The stability test of cream containing the extract was carried out at $4^{\circ} \mathrm{C}$, room temperature and $45^{\circ} \mathrm{C}$ for 2 months. The physical appearance, viscosity and $\mathrm{pH}$ of the prepared creams were evaluated, before and after the stability test.

\section{Statistical analysis}

The data was analyzed using a paired t-test and one-way analysis of variance (ANOVA), followed by Turkey's post hoc test using SigmaStat software version 3.5 (Systat Software Inc., San Jose, CA, USA). $p$-value $<0.05$ was considered a statistically significant difference.

\section{RESULTS}

Appearance, yield and phytochemical constituents

The $S$. acmella extract was obtained as a darkgreen semi-solid with yield of $1.6 \%(\mathrm{w} / \mathrm{w})$. The phytochemical constituents of the extract are shown in Table 2. The extract showed positive results for flavonoids and alkaloids. It had been reported that flavonoids possessed anticancer activity, whereas alkaloids exhibited antiproliferative activity on many different cancer cells $[22,23]$.

Table 2: Phytochemical profile of $S$. acmella extract

\begin{tabular}{llc}
\hline Constituent & Test & S. acmella \\
\hline Flavonoids & Shinoda & + \\
Alkaloids & Dragendorff & + \\
Tannins & Gelatin & - \\
Cyanogenic & Ferric chloride & - \\
glycosides & Grignard & - \\
Saponins & Frothing & - \\
Antraquinones & Brontragen & - \\
Terpenes \& & Liebermann & - \\
Steroids & burchard & \\
& Keller kilani & - \\
\hline
\end{tabular}

+ = Positive; - = Negative

Phenolic and flavonoid contents, and antioxidant activity of extract

The crude extract contained phenolic content of $62.8 \pm 5.2 \mathrm{mg} \mathrm{GAE} / \mathrm{g}$ and flavonoid content of $375.6 \pm 20.1 \mathrm{mg} \mathrm{RE} / \mathrm{g}$. It exhibited antioxidant activity with $\mathrm{IC}_{50}$ of $1.2 \pm 0.1 \mathrm{mg} / \mathrm{mL}$, relative to that of gallic acid $\left(\mathrm{IC}_{50}\right.$ of $\left.8.1 \pm 0.4 \mu \mathrm{g} / \mathrm{mL}\right)$.

\section{Cytotoxic effect of the extract}

The effect of the $S$. acmella extract on the cell death of breast cancer MCF-7 was explored by the SRB method. This study indicated that the extract increased the cell death of cancer cells in a dose- and time-dependent manner (Figure 1) with $\mathrm{IC}_{50}$ values of $80.2 \pm 6.8 \mu \mathrm{g} / \mathrm{mL}$ for $24 \mathrm{~h}$ (Figure $1 \mathrm{~A}$ ) and $37.1 \pm 1.1 \mu \mathrm{g} / \mathrm{mL}$ for $48 \mathrm{~h}$ (Figure 1 B).

\section{Anti-colony formation effect of the extract}

The effect of the extract on the replicative capability of breast cancer MCF-7 cells was performed by the clonogenic assay. This study showed that treatment with the extract caused decrease in the colony forming ability of MCF-7 cancer cells in dose-dependent manner (Figure 2 A). The extract strongly inhibited the ability of 
colony formation in MCF-7 cancer cells with $\mathrm{IC}_{50}$ value of $44.9 \pm 1.3 \mu \mathrm{M}$ (Figure $2 \mathrm{~B}$ ).
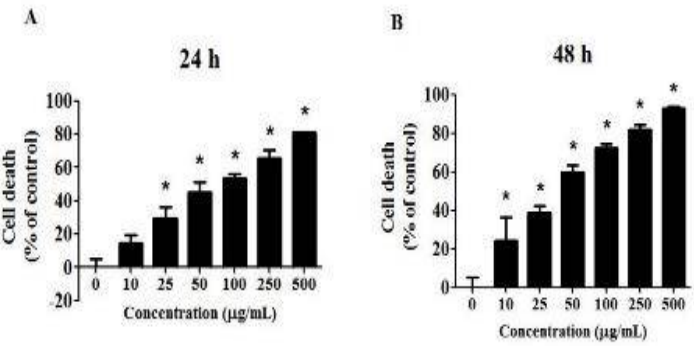

Figure 1: Effect of S. acmella extract on MCF-7 cancer cell death. Cells were treated with the extract $(0-500 \mu \mathrm{g} / \mathrm{mL})$ for $24 \mathrm{~h}(A)$ and for $48 \mathrm{~h}$ (B); ${ }^{*} p<0.05$ when compared with control.
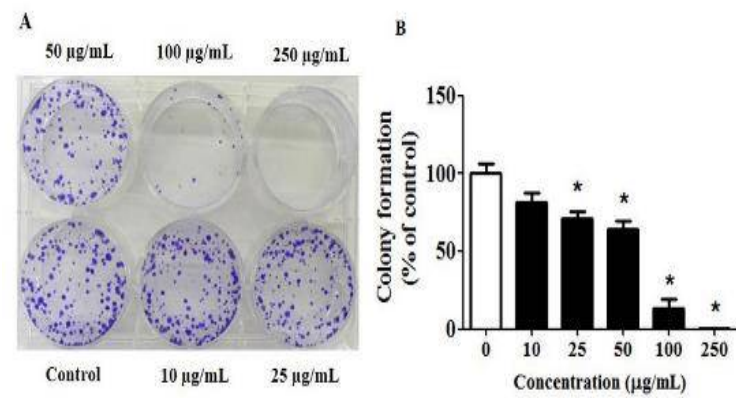

Figure 2: Effect of $S$. acmella extract on colony formation of MCF-7 cancer cell. The cells were exposed to extract $(0-250 \mu \mathrm{g} / \mathrm{mL})$ for $24 \mathrm{~h}$, cultured for 10-days and the cells were then stained with crystal violet and photographed (A). The graph showed the colony formation percentage relative to the control $(\mathrm{B}) ;{ }^{*} p<0.05$ when compared with the control

\section{Anti-migratory effect of the extract}

The effect of the extract on MCF-7 cell migration was determined by the wound healing method. The results revealed that the extract inhibited MCF-7 cancer cell migration and was significant at $50-100 \mu \mathrm{g} / \mathrm{mL}$ with an $\mathrm{IC}_{50}$ value of $53.5 \pm 8.9$ $\mu \mathrm{g} / \mathrm{mL}$ (Figure $3 \mathrm{~A}$ and $\mathrm{B}$ ).

\section{Characteristics and stability of cream bases}

All prepared cream base formulations showed homogeneous and smoothness texture with white color. The mean viscosity and $\mathrm{pH}$ of the prepared cream bases (Cream b-1, b-2 and b-3) are shown in Figure 4 . The viscosity of three cream formulations was in the range of 1,200 5,100 cps. The viscosity of cream base formulations increased with the increasing total weight of oil phase. The $\mathrm{pH}$ of all prepared cream bases was in the range of $6.8-7.4$. After the stability test, all cream bases remained homogeneous (i.e. no phase separation). The viscosity and the $\mathrm{pH}$ values of the creams decreased. Cream base-2 was selected and subjected to incorporate the extract $(0.01 \% \mathrm{w} / \mathrm{w})$ based on appropriate viscosity and $\mathrm{pH}$ following the stability test.
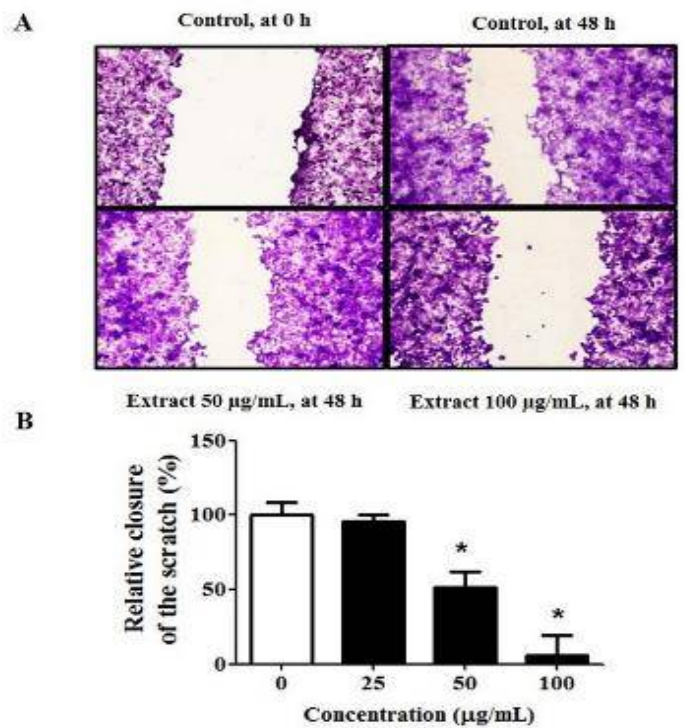

Figure 3: Effect of $S$. acmella extract on migration of MCF-7 cancer cell. The cells were exposed to extract $(0-100 \mu \mathrm{g} / \mathrm{mL})$ for $48 \mathrm{~h}$ and migration was captured using inverted microscopy $(x 10)(\mathrm{A})$. All results are expressed as percentage of control groups with three independent experiments and represent mean \pm SEM values $(\mathrm{B}) ;{ }^{*} p<0.05$ when compared with control
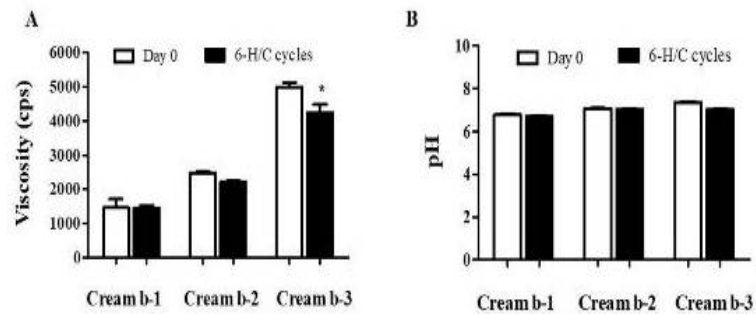

Figure 4: The viscosity $(\mathrm{A})$ and $\mathrm{pH}(\mathrm{B})$ of prepared cream bases (Cream b) before and after heatingcooling $(\mathrm{H} / \mathrm{C})$ cycling test; * $p<0.05$ when compared with control

\section{Characteristics and stability of creams containing extract}

The physical appearance, mean viscosity and $\mathrm{pH}$ of prepared cream base and cream containing the extract are illustrated in Figure 5. The cream containing the extract appeared light brown in color due to the color of the extract (Figure $5 \mathrm{~A}$ ). Compared with the cream base, the viscosity of the cream containing the extract was lower, while its $\mathrm{pH}$ was slightly higher (Figure $5 \mathrm{~B}$ ). Following a heating-cooling cycling test, the cream containing the extract showed no phase 
A

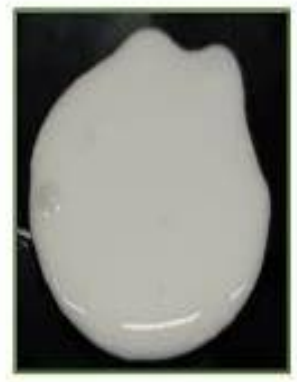

Cream base

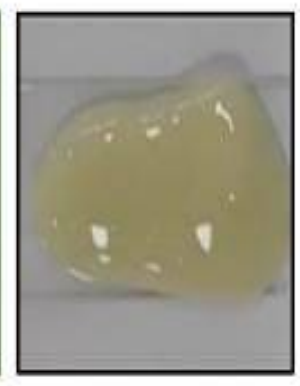

Cream containing the estract
B

\begin{tabular}{ccc}
\hline & \multicolumn{2}{c}{ Formulation } \\
\cline { 2 - 3 } Characteristic & Cream base & $\begin{array}{c}\text { Cream containing the } \\
\text { extract }\end{array}$ \\
\hline Homogeneity & Homogeneous & Homogeneons \\
Viscosity* & $2,468.7 \pm 42.4$ & $2,145.7 \pm 65.8$ \\
pH & $6.74 \pm 0.01$ & $6.93 \pm 0.01$ \\
\hline
\end{tabular}

- The viscesity was measured at $40 \mathrm{rpm}$ speed nith a CP52 cone and plate spindle

Figure 5: Physical appearance $(A)$ and $(B)$ of prepared cream base (Cream b-2) and cream containing the extract

separation. It also showed homogeneity following storage at $4^{\circ} \mathrm{C}$, room temperature and $45^{\circ} \mathrm{C}$ for two-month period (Figure 6). Under all conditions, the viscosities and $\mathrm{pH}$ of the creams decreased.

A

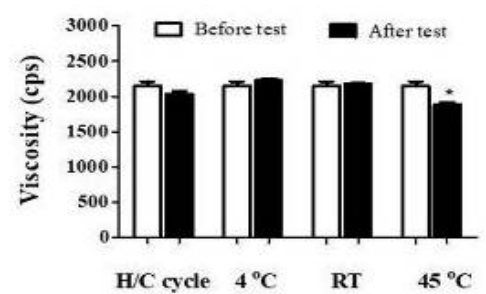

B

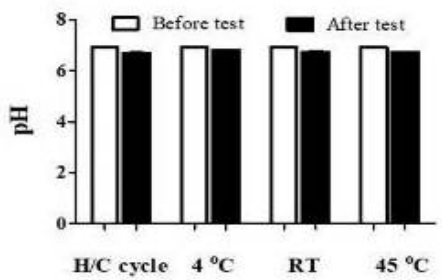

Figure 6: The viscosity $(\mathrm{A})$ and $\mathrm{pH}(\mathrm{B})$ of prepared cream containing the extract before and after heatingcooling $(\mathrm{H} / \mathrm{C})$ cycling test as well as at $4{ }^{\circ} \mathrm{C}$, room temperature (RT) and $45{ }^{\circ} \mathrm{C}$ for 2 months; ${ }^{*} p<0.05$ when compared with control

\section{DISCUSSION}

At present, the natural source of chemotherapeutic agent for cancer treatment is gaining interest. This study is the first report to study the anticancer effect of $S$. acmella extract. In this study, $S$. acmella extract was evaluated for its chemotherapeutic effects in terms of antioxidant activity, cytotoxicity, colony formation inhibition and cell migration suppression on MCF- 7 cells. SRB method, the clonogenic assay and the wound scratch healing assay are usually used to determine cell cytotoxicity, cell replicative ability and cell metastasis, respectively.

The results showed that $S$. acmella extract exhibited anti-breast cancer activities because the extract showed cytotoxicity and colony formation inhibition effects on human breast MCF-7 cancer cells. It also had an anti-migration effect, indicating inhibited metastasis on the MCF-7 cells [13,14]. This study showed agreement with previous studies showing that ethanolic extract of $S$. acmella possessed high antioxidant activity [24]. This is due to the extract consisting of phenolics and flavonoids content. The antioxidant effect of the $S$. acmella extract may be responsible for its cytotoxic effect since previous reports showed that tumor cell line treated with a high dose of antioxidants resulted in cytotoxic effect [11].

Spilanthol, an alkylamide, is the main active compound that can be found in $S$. acmella. It can be extracted from $S$. acmella using ethanol based on its amphiphilic structure [25]. Spilanthol is usually used for the treatment of toothaches due to its anesthetic and analgesic effects. However, there is no data concerning spilanthol used for cancer treatment or anticancer activity. Besides spilanthol, scopoletin, phenolic compound, vanillic acid and trans-ferulic acid have been found in the aerial part of $S$. acmella [18]. Scopoletin and vanillic acid have been reported to have a cytotoxic effect on cancer cells [26,27]. Thus, scopoletin and vanillic acid will be determined and used as a marker for antibreast cancer activity of the $S$. acmella extract. The mechanism of action will be identified in the future. 
This study suggests that $S$. acmella has potential anticancer effects and is therapeutic value added in medicinal plant. The application of the extract on breast skin as a local treatment for breast cancer is safer and might produce effective outcomes. Cream formulations are preferable for topical use. Thereafter, cream containing the extract was prepared. After stability testing, the physical appearance and $\mathrm{pH}$ of the prepared cream remained the same, while its viscosity decreased significantly. However, viscosity remained within the working range for topical use.

\section{CONCLUSION}

The results show that $S$. acmella extract exhibits anticancer effects against human breast cancer cells. The anticancer activity of the extract may be directly related to the induction of cytotoxicity, inhibition of colony formation and suppression of cell migration on MCF-7 cells. The cream containing the extract has been successfully formulated and shown to have potentials for use in topical breast cancer treatment.

\section{DECLARATIONS}

\section{Acknowledgement}

The authors would like to acknowledge the School of Pharmaceutical Sciences, University of Phayao, Thailand and Thailand Research Fund (MRG6080071) for financial support.

\section{Conflict of interest}

No conflict of interest is associated with this study.

\section{Contribution of authors}

We declare that this work was done by the authors named in this article, and all liabilities pertaining to claims relating to the content of this article will be borne by them. Supavadee Boontha designed the study and the experiments, and prepared the manuscript. Tasana Pitaksuteepong assisted in experimental work and appraised the manuscript. Benjaporn Buranrat was responsible for MCF-7 cell study. Thatcha Thoedyotin, Thanaphon Saengtabtim, Pathitta Im-erb and Natthamon Chaniad prepared the extract and participated in formulation of the cream.

\section{Open Access}

This is an Open Access article that uses a funding model which does not charge readers or their institutions for access and distributed under the terms of the Creative Commons Attribution License (http://creativecommons.org/licenses/by/ 4.0) and the Budapest Open Access Initiative (http://www.budapestopenaccessinitiative.org/rea d), which permit unrestricted use, distribution, and reproduction in any medium, provided the original work is properly credited.

\section{REFERENCES}

1. Carter D. New global survey shows an increasing cancer burden. Am J Nurs 2014; 114(3): 17.

2. American Cancer Society. Cancer facts \& figures 2016. Atlanta, GA: American Cancer Society; 2016.

3. Siegel RL, Miller KD, Jemal A. Cancer statistics. $C A$ Cancer J Clin 2016; 66: 7-30.

4. Kimman $M$, Norman $R$, Jan S, Kingston D, Woodward $M$. The burden of cancer in member countries of the Association of Southeast Asian Nations (ASEAN). Asian Pac J Cancer Prev 2012; 13: 411-420.

5. Venkatesan $P$, Raman TT, Ponnuraja $C$. Survival analysis of women with breast cancer under adjuvant therapy in South India. Asian Pac $J$ Cancer Prev 2011; 12: 1533-1535.

6. Alves-Silva JM, Romane A, Efferth T, Salgueiro L. North African Medicinal Plants Traditionally Used in Cancer Therapy. Front Pharmacol 2017; 8: 1-24.

7. Dubey $S$, Maity $S$, Singh $M$, Saraf $S A$, Saha $S$. Phytochemistry, Pharmacology and Toxicology of Spilanthes acmella: A Review. Adv Pharmacol Sci 2013: 423750-423750.

8. Prachayasittikul V, Prachayasittikul S, Ruchirawat $S$, Prachayasittikul V. High therapeutic potential of Spilanthes acemlla: a review. EXCLI J 2013; 12: 291312.

9. Suwanjang W, Khongniam B, Srisung S, Prachayasittikul $S$, Prachayasittikul $V$. Neuroprotective effect of Spilanthes acmella Murr. on pesticide-induced neuronal cells death. Asian Pac J Trop Med 2017; 10: 35-41.

10. Purushothaman $Y$, Gunaseelan $S$, Deepa Vijayakumar $S$. Spilanthes acmella and its medicinal uses - $A$ review. Asian J Pharm and Clin Res 2018; 11: 45-49.

11. Li WY, Chan SW, Guo DJ, Yu PH-F. Correlation between antioxidative power and anticancer activity in herbs from traditional Chinese medicine formulae with anticancer therapeutic effect. Pharm Biol 2007; 45: 541-546.

12. Redig AJ, McAllister SS. Breast cancer as a systemic disease: a view of metastasis. J Intern Med 2013; 274: 113-126.

13. Franken NAP, Rodermond HM, Stap J, Haveman J, van Bree C. Clonogenic assay of cells in vitro. Nat Protoc 2006; 1:2315-2319. 
14. Hulkower KI, Herber RL. Cell migration and invasion assays as tools for drug discovery. Pharmaceutics 2011; 3:107-124.

15. Taveira S, Lopez R, La Porta C. Topical administration of anticancer drugs for skin cancer treatment. In: Skin cancers-risk, factors, prevention and therapy. Rijeka, Croatia: InTech. 2011; 247-272.

16. Henriques L, Palumbo M, Guay M-P, Bahoric B, Basik M, Kavan $P$, Batist $G$. Imiquimod in the Treatment of Breast Cancer Skin Metastasis. J Clin Oncol 2014; 32: e22e25.

17. Krishnasamy SR, Almazan TH, Suero-Abreu GA, Jung $J Y$. Successful treatment of cutaneous metastatic breast cancer with topical treatments that potentially synergize with systemic therapy: A case series. JAAD Case Rep 2018; 4: 711-715.

18. Ansel H, Allen, L, Popovich, N. Ansel's Pharmaceutical Dosage Forms and Drug Delivery Systems, 9th Edition, Lippincott Williams \& Wilkins, Baltimore. 2011.

19. Joshi A, Harijan Kiran C: Physicochemical and phytochemical investigation of the roots of Hydnocarpus pentandrus (Buch.-Ham.) Oken. Int J Pharm Sci Rev Res 2014; 25:260-265.

20. Buranrat B, Suwannaloet $W$, Naowaboot J. Simvastatin potentiates; doxorubicin activity against MCF 7 breast cancer cells. Oncol Lett 2017; 14: 6243[6250.
21. Buranrat B, Mairuae N, Kanchanarach W. Cytotoxic and antimigratory effects of Cratoxy formosum extract against hepG2 liver cancer cells. Biomed Rep 2017; 6: 441-448.

22. Chahar MK, Sharma N, Dobhal MP, Joshi YC. Flavonoids: a versatile source of anticancer drugs. Pharmacogn Rev 2011; 5(9): 1-12.

23. Lu JJ, Bao JL, Chen XP, Huang M, Wang YT. Alkaloids isolated from natural herbs as the anticancer agents. Evid Complement Alternat Med 2012; 1-12.

24. Prachayasittikul S, Suphapong $S$, Worachartcheewan $A$, Lawung R, Ruchirawat S, Prachayasittikul V. Bioactive metabolites from Spilanthes acmella Murr. Molecules 2009; 14: 850-867.

25. Silveira N, Sandjo LP, Biavatti MW. Spilanthol-containing products: A patent review (1996-2016). Trends Food Sci Tech 2018; 74: 107-111.

26. Asgar MA, Senawong G, Sripa B, Senawong $T$. Scopoletin potentiates the anti-cancer effects of cisplatin against cholangiocarcinoma cell lines. Bangladesh $\mathrm{J}$ Pharmacol 2015; 10: 69-77.

27. Vinoth A, Kowsalya R. Chemopreventive potential of vanillic acid against 7,12 -dimethylbenz (a) anthraceneinduced hamster buccal pouch carcinogenesis. J Can Res Ther 2018; 14: 1285-1290. 